\title{
Performance evaluation and damage assessment of buildings subjected to seismic loading
}

\author{
S. Chandrasekaram ${ }^{1}$, G. Serino ${ }^{2}$ \& V. Gupta ${ }^{1}$ \\ ${ }^{I}$ Department of Civil Engineering, Institute of Technology, \\ Banaras Hindu University, India \\ ${ }^{2}$ Department of Structural Engineering, University of Naples Federico II, \\ Naples, Italy
}

\begin{abstract}
The intent of performance-based earthquake engineering is to provide methods for designing, constructing and maintaining buildings, such that they are capable of providing predictable performance when affected by earthquakes. This methodology examines the behavior of a structure at various service levels. Inherently, the performance-based design concept implies the definition of multiple target performance (damage) levels that are expected to be achieved, or at least not exceeded, when the structure is subjected to earthquake ground motion of a specified intensity. Pushover analysis is one of the tools for estimating earthquake demands at various performance levels. This paper focuses on the pushover analysis of multistory structures subjecting them to monotonically increasing lateral forces with an invariant height wise distribution until the preset performance level (target displacement) is reached. It also discusses the collapse mechanism illustrating the sequence of plastic hinge formation before failure with a special mention to the various performance levels namely immediate occupancy (IO), life safety (LS) and collapse prevention (CP) respectively. Conclusions are drawn based on the numerical studies conducted to emphasis the parameters associated with the performance based design of multistory RC framed buildings.
\end{abstract}

Keywords: pushover analysis, performance evaluation, collapse mechanism, performance based seismic engineering. 


\section{Introduction}

The main objective of the seismic design of buildings is to avoid total catastrophic damage so that structural damages caused, if any, could be repaired after the earthquake event. However, considering economic losses, the requirement for better performance has led to the development of performance-based seismic design methodology. A nonlinear analysis tool is required to evaluate earthquake demands at various performance levels. Pushover analysis is widely accepted as the primary tool (Chopra [1], Chopra [2] and Chandrasekaran [3]) because of its simplicity compared with other detailed dynamic analysis procedures. Since prescribed loading used in pushover analyses does not represent the potential range of loading experienced in dynamic response, results obtained by pushover analyses are at best an approximation of the nonlinear behavior of structures under earthquake forces. With the increase in magnitude of monotonic loading, weak links and failure modes in the multistory RC frames are usually formed. Though the name performance-based engineering is new, the basic concept of developing buildings and structures that will meet expected performance levels under different ground motion scenarios is certainly not. Performance based design procedures are being increasingly used by the researchers and engineers to estimate the seismic demand at structural and component levels (Li [4], Christopoulous [5] and Kappos [6]). The structural capacity for a particular pattern of loading can be understood in a better form with the help of pushover analysis through the sequence of hinge formation before ultimate collapse. Alternative simplified nonlinear procedures were also discussed by several researchers (Fajfar [7] and Aschheim [8]) to predict the earthquake response of buildings and their applicability.

Pushover analysis procedure is an effective nonlinear static analysis that accounts for material and geometric nonlinearities as well. This analysis requires numerous subjective parameters like hinge properties at component level, location of hinges with respect to the accepted performance levels like i) immediate occupancy (IO), ii) life safety (LS) and iii) collapse prevention (CP) to describe the response behavior of the structure. The calculations are multivalued and computationally intensive requiring judgement to interpret the solutions with respect to the case being studied. Performance point is the intersection point of pushover curve and seismic demand curves. If performance point exists and damage state at that point is acceptable, then the structure is considered to be safe for that point, i.e. for the corresponding base shear and displacement values. Capacity of structure and demand imposed on it are dependent on each other. As demand on structure increases, stiffness decreases resulting in change in the period of the structure. Also damping increases due to yielding of the structure. Hence performance points can be established by various methods (Murthy [9]) namely capacity spectrum method (as per ATC 40 [10]), R-Factor method and Displacement co-efficient method (as per FEMA 440 $[11])$. 
From the pushover curves, three major properties of new buildings namely initial stiffness, strength and ductility can be qualitatively assessed. Effective damping increases with damage and is given by

$$
\begin{aligned}
& \beta_{\text {eff }}=\beta_{0}+0.05 \\
& \beta_{0}=\frac{1}{4 \pi}\left[\frac{E_{D}}{E_{\text {so }}}\right]
\end{aligned}
$$

where $E_{D}$ and $E_{S O}$ are cyclic energy and elastic energy respectively (Murthy [9]).

\section{Numerical studies and discussions}

Seismic analysis of a ten storey RC framed building was performed using pushover analysis. Fig. 1 shows the plan and elevation of the RC framed building model considered for the analysis. Slab thickness is taken as $150 \mathrm{~mm}$. $500 \mathrm{~mm}$ square column are reinforced with $16 \#$ of $25 \mathrm{~mm}$ diameter bars \& $8 \mathrm{~mm}$ transverse reinforcement @ 200mm c/c whereas beam of size 300 x 450mm

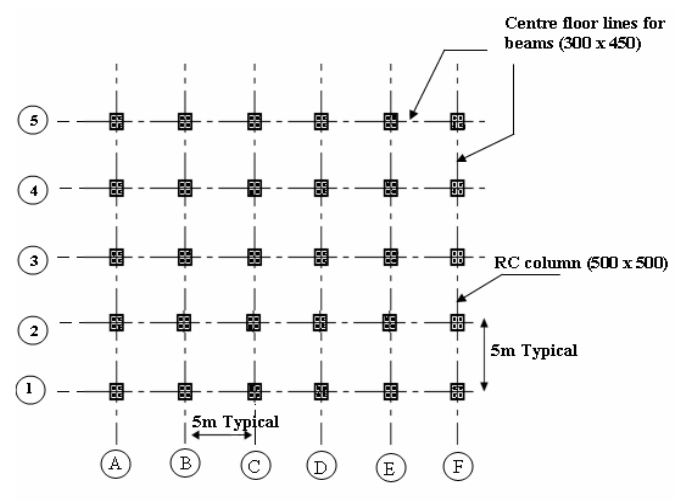

PLAN

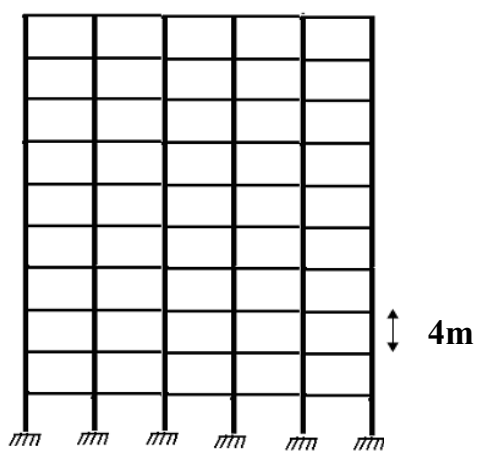

ELEVATION

Figure 1: Plan and elevation of ten-storey building. 
(overall) with 5 bars of $22 \mathrm{~mm}$ diameter as tension steel and 4 bars of $16 \mathrm{~mm}$ diameter as compression steel with shear reinforcement of $8 \mathrm{~mm}$ diameter, two legged vertical stirrups @ 230mm c/c are used in the building model taken for the study. M25 mix and HYSD bars are used in the members. Modulus of elasticity of steel is taken as $2.1 \times 10^{5} \mathrm{~N} / \mathrm{mm}^{2}$ and that of concrete is taken as 2.5 $x 10^{4} \mathrm{~N} / \mathrm{mm}^{2}$. Plastic hinges of type P-M-M are used in the analysis. The building is assumed to be located in Zone V (IS-1893 [12]) with soil condition as 'medium soil'. The macro-properties of strength, namely, Moment hinge M- $\varphi$ property with P-M interaction for beams and columns were derived (Baker [13]) and shown in Fig. 2. The acceptable performance levels namely IO, LS and CP are tagged on the respective $M-\varphi$ curves of beam and column hinges as shown in Fig. 2. Structural damping is taken as $5 \%$ of the critical. Response spectra given in the IS code [12] is used as input design spectrum. Pushover analysis was performed using SAP 2000 Nonlinear (Version 8.0). The building is modeled in the software and strength properties at various hinge locations (at beams and columns) are defined. Locations of hinges are marked from the centre of the beam and column junction respectively at 0.044 and 0.956 times of span of the beam/column length. Capacity spectrum method as recommended by ATC 40 [10] is used to determine the performance point and is determined based on the original demand spectra of 5\% damping (Chopra [14]) without considering the effective increase in damping. The following steps are adopted while performing pushover analysis in SAP 2000 Nonlinear (Version 8.0) software.

- The building was modeled with appropriate geometric properties of various components.

- Material and section properties were given as input, appropriate to the model under consideration.

- Nonlinear hinge properties (both for column and beam hinges) were given from the respective $\mathrm{M}-\varphi$ and P-M interaction curves.

- Mass source was initiated to impose self-weight of the building.

- Various load cases namely dead load, pushover load etc were assigned.

- Possible location of hinge formation in beams and columns were then assigned under miscellaneous assignments.

- Analysis cases were defined such that pushover load was applied subsequently after the application of dead load (for e.g. Pushover - nonlinear, load application - displacement controlled). The building is loaded to a monitored roof or tip displacement of $1.6 \mathrm{~m}$ (i.e. $4 \%$ of the total height of the building).

- The lateral force profile used for pushover analysis is taken from the first mode of vibration of the building structure.

- These loads were applied with an invariant height wise distribution until the preset performance level (target displacement) is reached.

- Computational parameters were set in the system (by trial and error/iteration) to fix the number of time steps (and the step size) along with the convergence criteria.

- Pushover curves were obtained for any specified node of the building (intersection of beam and column) along with the coordinates of the performance point. 

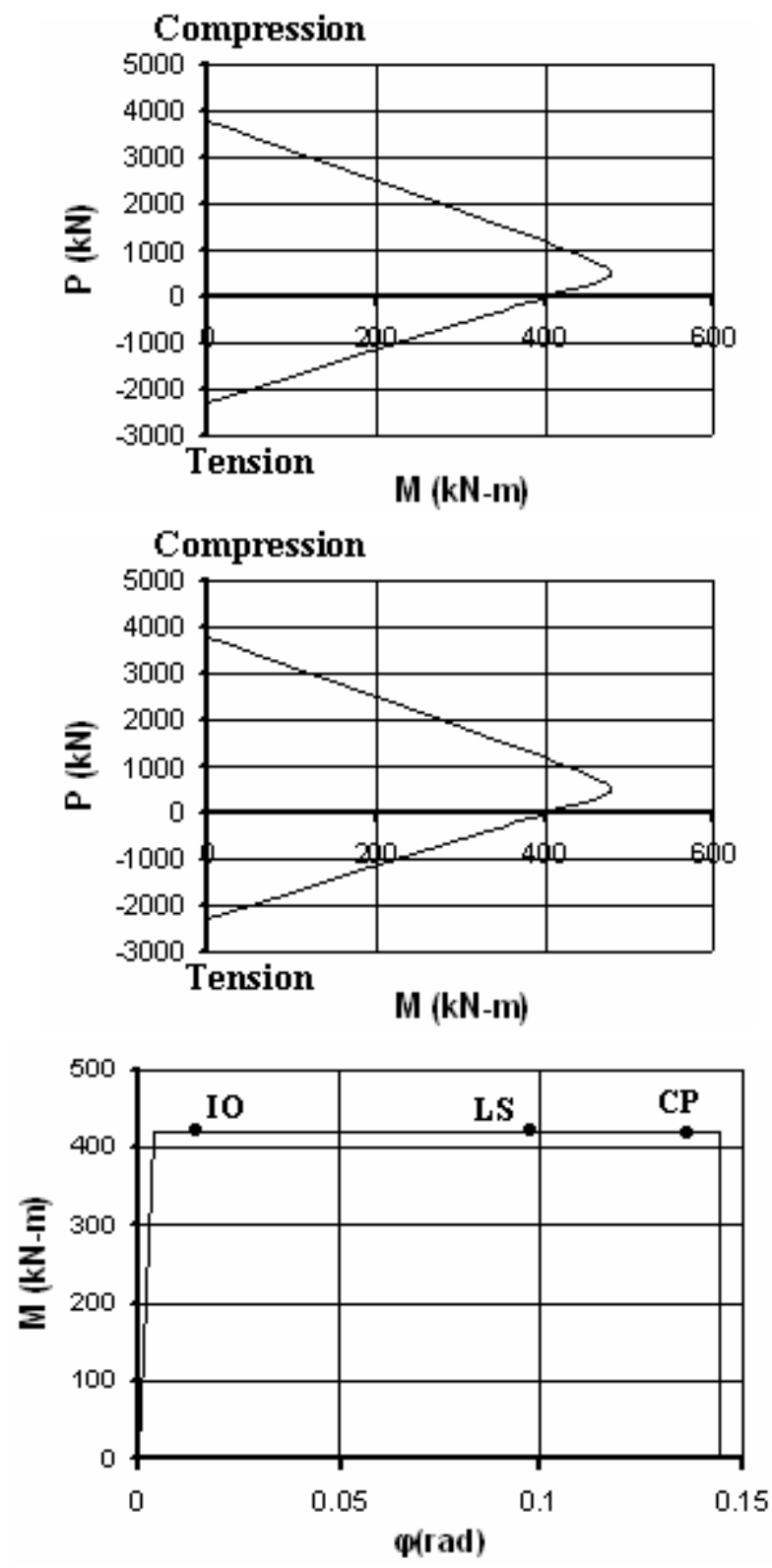

(a)

Figure 2: Derived strength properties of beams and columns. (a) Beam hinge properties. (b) Column hinge properties. 

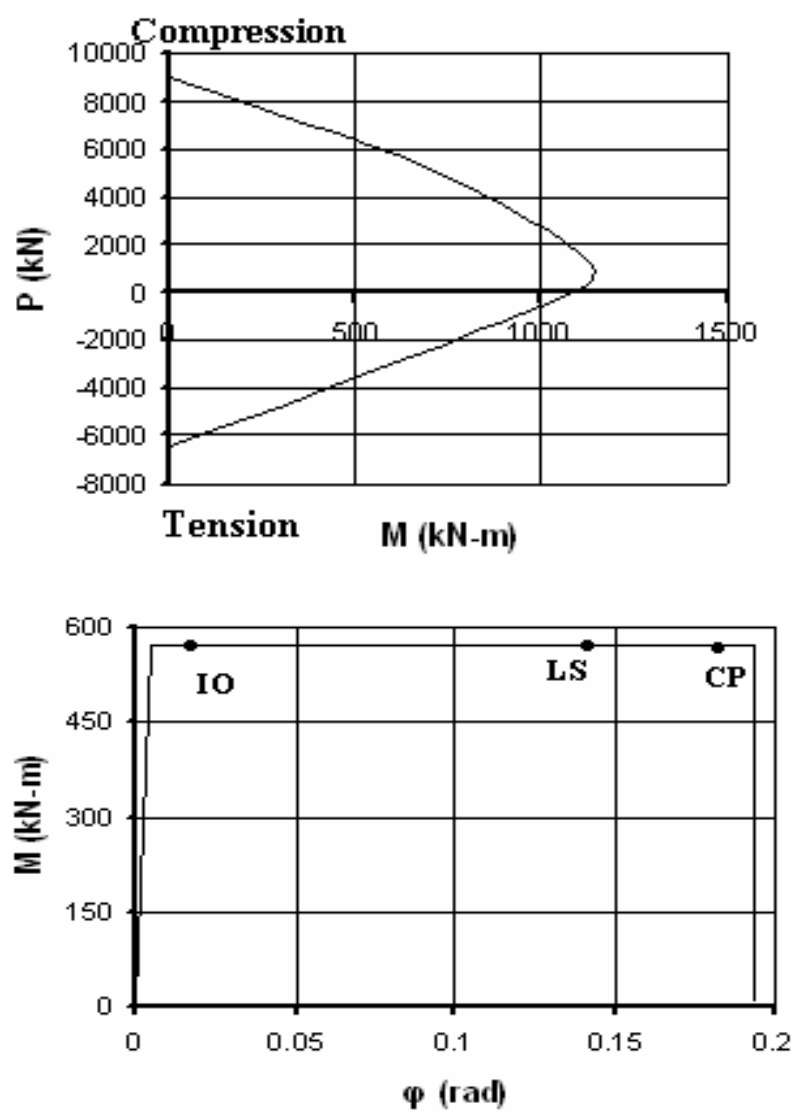

(b)

Figure 2: Continued.

- Performance point was obtained based on the design spectra from IS 1893 with 5\% damping.

- The table corresponding to the formation of hinges (including their location i.e. in beams or in columns) indicating the number of hinges formed and the corresponding base shear was traced.

- Pushover curves were plotted subsequently and the results from the tables are interpreted.

Pushover analysis of the building was performed for the pre-set target displacement (of the roof/tip) so as to also examine the hinges being formed at various performance levels, namely IO, LS and CP respectively. If the hinges are being formed at the CP level, then the pushover analysis was repeated for changed combination of target displacement until no hinges are being formed at the performance level in $\mathrm{CP}$ region and thus the analysis becomes iterative. Pushover curves are finally obtained for the target displacement (of the roof/tip 


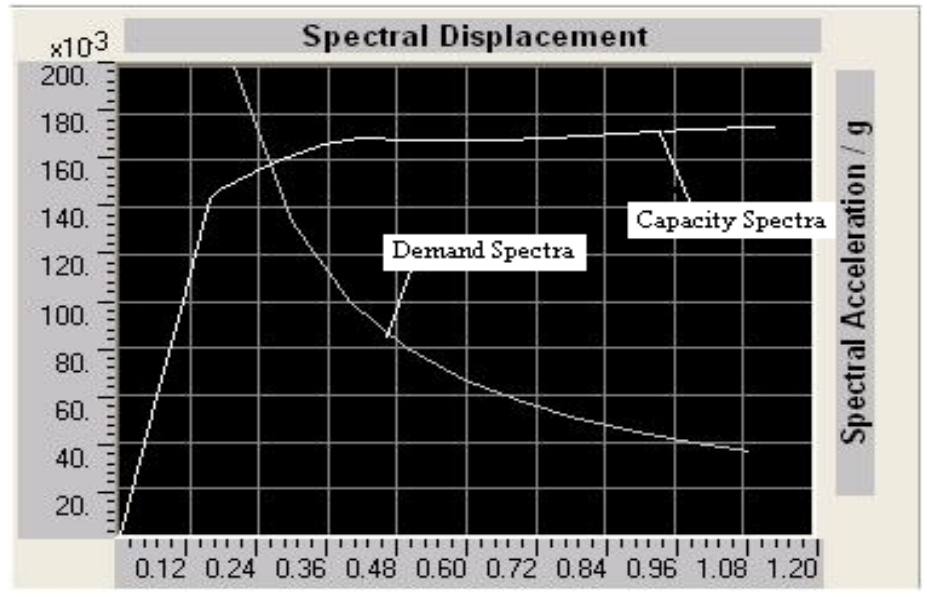

Figure 3: $\quad$ Pushover performed to a target displacement of $1.6 \mathrm{~m}$ to obtain performance point.

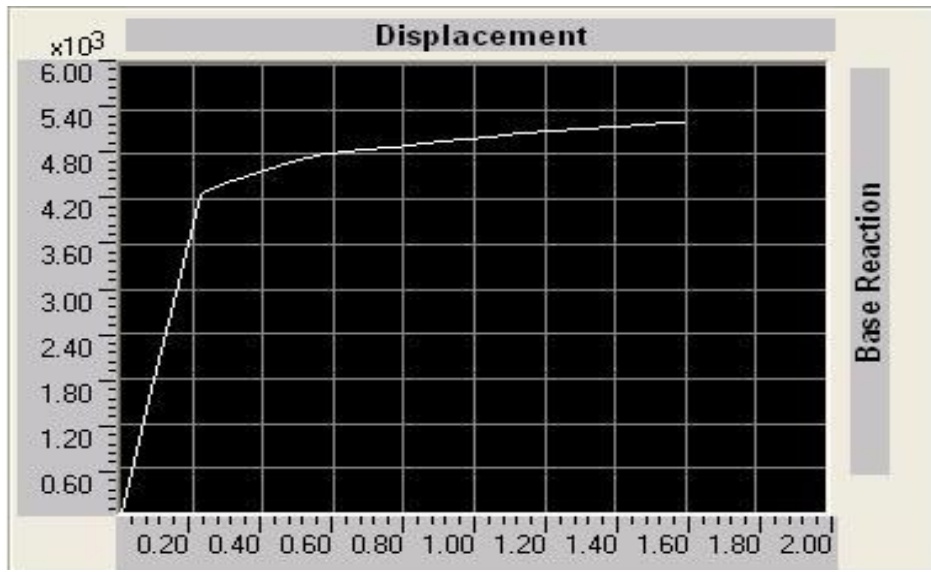

Figure 4: $\quad$ Pushover curve for the roof tip.

of the building) of $4 \%$ of the height of the building for no hinges being formed at $\mathrm{CP}$ region of performance level. The pushover analysis is terminated after the preset target displacement is reached. Since performance point is established well before the target displacement is reached, the capacity spectrum curve obtained is found to be satisfactory.

Fig. 3 shows the capacity spectrum after performing pushover analysis to a target displacement (tip displacement) of $1.6 \mathrm{~m}$ and subsequently performance point was obtained after sufficient iterations. The coordinates of the performance point $\left(\mathrm{Sa} / \mathrm{g}, \mathrm{S}_{\mathrm{D}}\right)$ with respect to the design spectra as specified by the code [12] can be seen as $(0.156,0.270)$. The corresponding base shear and tip displacement are $4554.36 \mathrm{kN}$ and $0.3871 \mathrm{~m}$ respectively. Fig. 4 shows the pushover curve 
(Resultant base shear vs. monitored tip displacement) obtained for the building from pushover analysis. Formation of hinges at various performance levels during pushover analysis is given in Table 1. It is seen from the table that no hinge formation has taken place in LS-CP range (and further) at collapse stage, which has been imposed as performance criteria during the pushover analysis.

Table 1: $\quad$ Hinge formation at various performance levels.

\begin{tabular}{|c|c|c|c|c|c|c|}
\hline Step No. & $\begin{array}{c}\text { Displacement } \\
\text { (in m) }\end{array}$ & $\begin{array}{c}\text { Base Force } \\
\text { (in kN) }\end{array}$ & A-B & B-IO & $\begin{array}{c}\text { IO- } \\
\text { LS }\end{array}$ & $\begin{array}{c}\text { LS- } \\
\text { CP }\end{array}$ \\
\hline 0 & 0.0000 & 0 & 1920 & 0 & 0 & 0 \\
\hline 1 & 0.0800 & 1533 & 1920 & 0 & 0 & 0 \\
\hline 2 & 0.1600 & 3067 & 1920 & 0 & 0 & 0 \\
\hline 3 & 0.2161 & 4143 & 1878 & 42 & 0 & 0 \\
\hline 4 & 0.2218 & 4216 & 1694 & 226 & 0 & 0 \\
\hline 5 & 0.2240 & 4235 & 1642 & 278 & 0 & 0 \\
\hline 6 & 0.2312 & 4278 & 1595 & 325 & 0 & 0 \\
\hline 7 & 0.2332 & 4287 & 1580 & 340 & 0 & 0 \\
\hline 8 & 0.2457 & 4323 & 1504 & 416 & 0 & 0 \\
\hline 9 & 0.2810 & 4392 & 1454 & 466 & 0 & 0 \\
\hline 10 & 0.3724 & 4543 & 1428 & 492 & 0 & 0 \\
\hline 11 & 0.4854 & 4711 & 1366 & 446 & 108 & 0 \\
\hline 12 & 0.5719 & 4800 & 1314 & 284 & 322 & 0 \\
\hline 13 & 0.5878 & 4810 & 1310 & 264 & 346 & 0 \\
\hline 14 & 0.6887 & 4862 & 1308 & 194 & 418 & 0 \\
\hline 15 & 0.7687 & 4902 & 1308 & 140 & 472 & 0 \\
\hline 16 & 0.9114 & 4972 & 1302 & 76 & 542 & 0 \\
\hline 17 & 1.0406 & 5031 & 1286 & 76 & 558 & 0 \\
\hline 18 & 1.1345 & 5073 & 1276 & 41 & 603 & 0 \\
\hline 19 & 1.2224 & 5112 & 1272 & 40 & 608 & 0 \\
\hline 20 & 1.3075 & 5148 & 1266 & 46 & 608 & 0 \\
\hline 21 & 1.4041 & 5180 & 1253 & 59 & 608 & 0 \\
\hline 22 & 1.5554 & 5217 & 1247 & 61 & 612 & 0 \\
\hline 23 & 1.6000 & 5226 & 1243 & 65 & 612 & 0 \\
\hline & & & & & & \\
\hline
\end{tabular}

Based on the numerical studies conducted, it is seen that pushover analysis brings a thorough insight of the failure pattern since it presents the sequence of hinges formed along with the (pre-set) accepted level of performance. Formation of hinges at different steps (monitored tip displacement) of pushover analysis along with the resultant base shear at those tip displacements are also obtained from the pushover analysis which guides the structural design process so that the building behaves in a predefined pattern under the design seismic loading. For example, it can be seen from Table 1 that there are no hinges formed beyond the IO level till step 10. Now, if the acceptability level for this particular building is Immediate occupancy (IO), as desired by the structural designer, based on the 
importance of the building being analyzed, one can consider resultant base shear and tip displacement values at step 10 (Base shear $=4543 \mathrm{kN}$ and Tip Displacement $=0.3724 \mathrm{~m}$ ) as design values for the building (for the given acceptability criteria).

\section{Concluding remarks}

The paper illustrates the performance-based design methodology to be employed in seismic engineering in a step-by-step manner. The building can be made to perform in a pre-defined manner under seismic forces while estimating its seismic capacity. This is a considerable advantage gained by employing pushover analysis. Pushover analysis brings a thorough insight of failure pattern of the building and hence provides an option (to the designer) to design the structure according to its intended use. Although, adaptive pushover techniques exist to account for the varying dynamic characteristics following yielding of the components, conventional pushover analysis is used in this study (i.e. with an invariant lateral force distribution), as the aim of the paper is to simply demonstrate application of performance-based design in earthquake engineering.

\section{References}

[1] Chopra, A.K., Goel, R.K., A modal pushover analysis procedure for estimating seismic demands for buildings. Journal of Earthquake Engineering and Structural dynamics, 31(3), pp. 561-582, 2002.

[2] Chopra, A.K., Goel, R.K., A modal pushover analysis procedure to estimate seismic demands for un-symmetric buildings, Journal of Earthquake Engineering and Structural dynamics, 33(8), pp. 903-927, 2004.

[3] Chandrasekaran, S. \& Roy, A., Seismic evaluation of multi storey RC frame using Modal pushover analysis, International Journal of Nonlinear Dynamics and chaos in Engineering Systems, 4(43), pp. 329-342, 2006.

[4] Li, Q. \& Ellingwood, B.R., Performance evaluation and damage assessment of steel frame buildings under main shock-aftershock earthquake sequences, Journal of Earthquake Engineering \& Structural Dynamics, 36(3), pp. 405-427, 2007.

[5] Christopoulous, C., Performance based seismic design of MDOF Structure with explicit consideration of residual deformation, ISET Journal of Earthquake Technology, 41(1), pp. 53-73, 2004.

[6] Kappos, A.J. \& Panagopoulas, G., Performance-based seismic design of 3D RC buildings using inelastic static and dynamic analysis procedures, ISET Journal of Earthquake Technology, 41(1), pp. 141-158, 2004.

[7] Fajfar, P., A nonlinear analysis method for performance-based seismic design, Earthquake Spectra (EERI), 16(3), pp. 573-592, 2000.

[8] Aschheim, M.A., Tjhin, T. \& Mehmet, I., The Scaled non-linear dynamic procedure: A practical technique for overcoming limitations of the Nonlinear static procedure, ISET Journal of Earthquake Technology, 41(1), pp. 127-140, 2004. 
[9] Murthy, C.V.R and Rai, D.C., Push over analysis of buildings, Lecture notes of Short Course on Nonlinear seismic analyses of structures, IITKanpur, 2006.

[10] ATC-40 Report, Seismic Evaluation and Retrofit of Concrete Buildings, 1996

[11] FEMA 440, Improvement of Nonlinear Static Seismic Analysis Procedures, June 2005.

[12] IS 1893 (Part 1), Criteria for Earthquake Resistant Design of Structures, Part 1: General Provisions and Buildings, Fifth revision, Bureau of Indian Standards, New Delhi, India, 2002.

[13] Ramakrishnan, V. \& Arthur, P. D., Ultimate strength design for structural concrete, A.H. Wheeler \& Co (P) Ltd, Allahabad, India, 1988.

[14] Chopra A., Dynamics of structures- Theory \& applications to Earthquake Engineering”, Pearson Education, 2004. 